\title{
Call for Special Issue Papers: Perspectives of Social Informatics
}

\author{
Deadline for Manuscript Submission: 31 July 2021
}

Special Issue Editors:

Prof. Dr. Vasja Vehovar (iD, University of Ljubljana, Slovenia

Dr. Zdenek Smutny (D), Prague University of Economics and Business, Czech Republic

Prof. Dr. Alice R. Robbin (D), Indiana University, Bloomington, USA

\section{Special issue information}

As was stated in (Smutny \& Vehovar, 2020): "Research activities related to social informatics are expanding, even as community fragmentation, topical dispersion, and methodological diversity continue to increase. Specifically, the different understandings of social informatics in regional communities have strong impacts, and each has a different history, methodological grounding, and often a different thematic focus." Therefore, this special issue would like to present different perspectives on social informatics that arose in the world (see overviews e.g. in Fichman et al., 2015; Fichman \& Rosenbaum, 2014; Smutny, 2016; Petrič \& Atanasova, 2013). Therefore, the special issue will be divided into two parts that cover the full scope of social informatics. The first part will focus on theoretically oriented articles and the second part on empirically oriented articles. The special issue is also open to articles that have a thematically close research focus (e.g. socio-informatics) and/or use regional terms that can be translated into English as social informatics, e.g. samfunnsinformatikk, sosialinformatikk, sosioinformatikk, sozioinformatik (Wulf et al., 2018), sozialinformatik (Kreidenweis, 2012), социальная информатика (Sokolova, 2018; Kolin, 2015; Kolin, 2011), družboslovna informatika (Vehovar, 2006), 社会情報学 (Kurosu, 2010) and others.

\section{Theoretically oriented papers on social informatics}

We welcome the perspectives of scholars (researchers, academics) from different regions on social informatics and its historical roots, current research and issues, future directions, methodological approaches and regional institutionalization. We particularly encourage authors to use regional (non-English) literature when they describe their regional approach or school of thought (does not apply to English speaking regions).

\section{Empirically oriented papers relevant to social informatics}

We prefer a broad international view of social informatics research that connects, at an interdisciplinary level, informatics (especially computer and information science and information systems) and the social sciences. Therefore, suitable topics for empirically oriented manuscripts include, but are not limited to, following: 
- ambient intelligent systems

- cyberculture

- dynamics of social collaborative systems and collective intelligence

- e-research and e-science(s)

- economic, cultural, and organizational dimensions of computerization

- health informatics

- human-computer interaction

- ICT in education

- information ethics

- information processes and exchanges in organizations and society

- information society

- internet communication and media
- impact of IoT on social life

- mining big social data

- opinion mining and social media analytics

- social applications of the semantic Web

- social changes (on the background of ICT)

- social media impact

- sociotechnical approaches in research

- sustainable development of information society

- systems approach to sociotechnical relationships

- virtual communities

We encourage authors to use social informatics literature as a theoretical basis or starting-point for their research or perspective. The References section of this Call for papers provides a list of recommended conceptually focused sources.

\section{About Acta Informatica Pragensia journal}

Acta Informatica Pragensia (ISSN 1805-4951) is a peer-reviewed journal on social and business aspects of informatics. It covers mainly the theory, application and management of information systems, as well as interactions between information and communication technologies and people. All articles are published in DIAMOND OPEN ACCESS. The journal has NO CHARGE for article publication. All accepted manuscripts have free professional English proofreading.

Abstracting and Indexing: Scopus (Elsevier), DBLP Computer Science Bibliography, RSCI Russian Science Citation Index, Open J-Gate, CEEOL, ERIH PLUS, DOAJ and other databases.

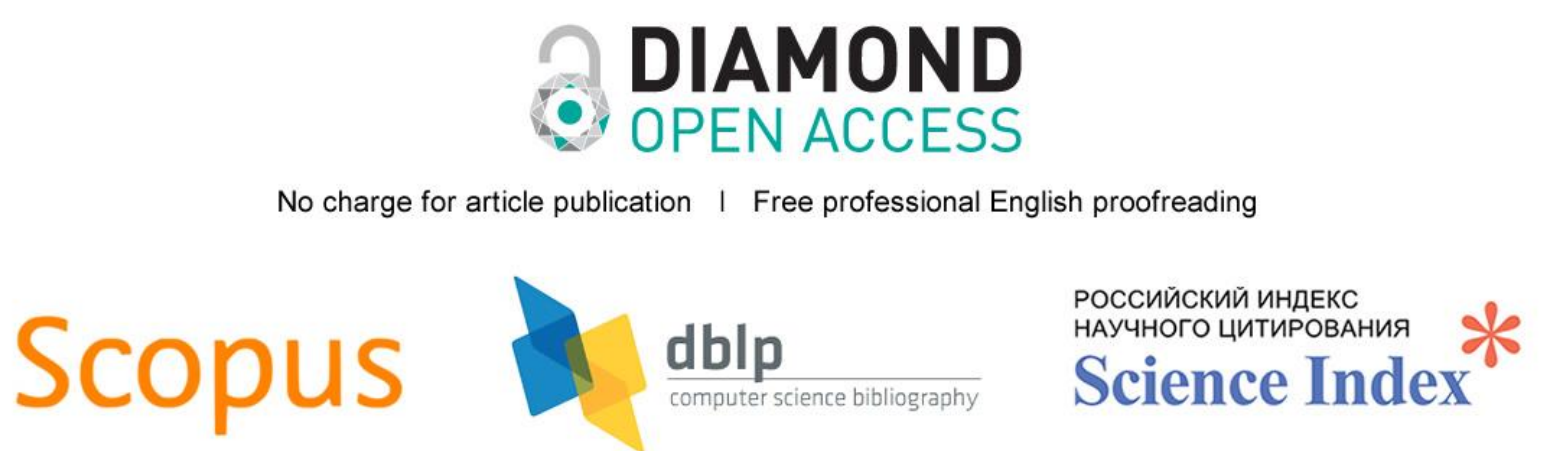




\section{Notes for prospective authors}

Submitted papers should not have been previously published nor be currently under consideration for publication elsewhere. All papers must be submitted online. To submit a paper, please read our Submitting articles page. When you are submitting a manuscript, please select the "Special issue" option in "Section". If you have any suggestions or questions regarding the subject matter, please contact special issue editor Zdenek Smutny (zdenek.smutny@vse.cz).

Before submitting your paper, please make sure you carefully read the instructions to authors. The journal has no strict formatting requirements on submission. There is no restriction on the length of manuscripts. Accepted articles will be immediately published on the journal website with digital object identifier (DOI) prior to the release of the special issue.

\section{Important dates}

Deadline for manuscript submissions: 31 July 2021

Notification to authors within three weeks.

Special issue will be published in December 2021.

\section{Visit the instructions for authors}

\section{$\underline{\text { Submit your paper for peer review online }}$}

\section{Selected references}

Davenport, E. (2008). Social informatics and sociotechnical research-A view from the UK. Journal of Information Science, 34(4), 519-530. https://doi.org/10.1177/0165551508091011

Fichman, P., \& Rosenbaum, H. (2014). Social informatics: Past, present and future. Cambridge Scholars Publishing.

Fichman, P., Sanfilippo, M. R., \& Rosenbaum, H. (2015). Social informatics evolving. Morgan \& Claypool Publishers.

Kling, R. (2000). Learning about information technologies and social change: The contribution of social informatics. The Information Society, 16(3), 217-232. https://doi.org/10.1080/01972240050133661

Kling, R. (2007). What is social informatics and why does it matter?. The Information Society, 23(4), 205-220. https://doi.org/10.1080/01972240701441556

Kolin, K. K. (2011). Social informatics today and tomorrow. TripleC: Communication, Capitalism \& Critique, 9(2), 460-465. https://doi.org/10.31269/triplec.v9i2.299

Kolin, K. K. (2015). Social informatics: Russian scientific school and future research directions. Systems and Means of Informatics, 25(4), 175-193. https://doi.org/10.14357/08696527150413

Kreidenweis, H. (2012). Lehrbuch Sozialinformatik. UTB.

Kurosu, T. (2010). In search of a paradigm of socio-informatics: On socio-informatics and social informatics. Journal of Socio-Informatics, 3(1), 69-81. https://doi.org/10.14836/jsi.3.1_69

Meyer, E. T., Shankar, K., Willis, M., Sharma, S., \& Sawyer, S. (2019). The social informatics of knowledge. Journal of the Association for Information Science and Technology, 70(4), 307-312. https://doi.org/10.1002/asi.24205 
Petrič, G., \& Atanasova, S. (2013). Družboslovna informatika: Razvojne konvergence in raziskovalni dosežki. Teorija in praksa, 50(2), 347-375.

Robbin, A. (2007). Rob Kling In Search of One Good Theory. The Information Society, 23(4), 235-250. https://doi.org/10.1080/01972240701444154

Smutny, Z. (2016). Social informatics as a concept: Widening the discourse. Journal of Information Science, 42(5), 681-710. https://doi.org/10.1177/0165551515608731

Smutny, Z., \& Vehovar, V. (2020). Social informatics research: Schools of thought, methodological basis, and thematic conceptualization. Journal of the Association for Information Science and Technology, 71(5), 529539. https://doi.org/10.1002/asi.24280

Sokolova, I. V. (2018). Социальная информатика. Квант Медиа.

Vehovar, V. (2006). Social informatics: An emerging discipline? In Social informatics: An information society for all? In remembrance of Rob Kling (pp. 73-85). Springer. https://doi.org/10.1007/978-0-387-37876-3_6

Wulf, V., Pipek, V., Randall, D., Rohde, M., Schmidt, K., \& Stevens, G. (Eds.) (2018). Socio-informatics: $A$ Practice-based Perspective on the Design and Use of IT Artifacts. Oxford University Press.

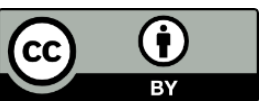

Copyright (c) 2020 by the author(s). Licensee Prague University of Economics and Business, Czech Republic. This article is an open access article distributed under the terms and conditions of the Creative Commons Attribution License (CC BY), which permits use, distribution and reproduction in any medium, provided the original publication is properly cited, see http://creativecommons.org/licenses/by/4.0/. No use, distribution or reproduction is permitted which does not comply with these terms.

Call for papers I Published: 3 October 2020 